\title{
SINGLE-STEP SYNTHESIS, CHARACTERIZATION AND ANTIMICROBIAL STUDIES OF NOVEL STEROIDAL 1', 2', 3'- THIADIAZOLES
}

\author{
NAZISH SIDDIQUI * AND SHAMSUZZAMAN ${ }^{b}$ \\ A*-Department of Ilmul Advia, Faculty of Unani Medicine, Aligarh Muslim University, Aligarh -202002, India \\ B- Department of chemistry, Aligarh Muslim University, Aligarh -202002 India
}

(Received: January 7, 2013 - Accepted: June 19,2013)

\begin{abstract}
A convenient one-step synthesis of steroidal thiadiazoles 7-9 from steroidal 6-ketone semicarbazones 1-3 with thionyl chloride has been reported. The steroidal 6-ketone thiosemicarbazones 4-6 under similar reaction conditions also provided the same products 7-9. The structures of these newly synthesized compounds have been established on the basis of their IR, ${ }^{1} \mathrm{H}$ NMR and ${ }^{13} \mathrm{C}$ NMR, elemental and analytical data. The synthesized compounds were screened for in vitro antimicrobial activity against different bacterial (gram positive and gram negative) and fungal strains. All the synthesized compounds showed significant activity against various micro-organisms.
\end{abstract}

Keywords: Steroidal thiadiazoles, Semicarbazones, thiosemicarbazones, Thionyl chloride, Antimicrobial activity.

\section{INTRODUCTION}

Recent studies reveals that incorporation of hetero atom (N/O/S) enhances the biological activities of steroidal molecules. The importance of heterocyclic compounds has long been recognized in the field of synthetic organic chemistry and thiadiazoles are well documented, especially after the discovery that some thiadiazoles are associated with wide variety of physiological activities such as antiaflatoxigenic ${ }^{1}$, antimicrobial ${ }^{2-6}$, anti-phage ${ }^{7}$, tuberculostatic 8,9 , anticonvulsant ${ }^{10}$, activity as well as fungicidal ${ }^{11}$, and amoebicidal ${ }^{12}$ properties. Besides this thiadiazoles are useful as plant growth regulator ${ }^{13,14}$ antidiabetics ${ }^{15}$, and chemotherapeutic ${ }^{16}$ agents. They have also been used as a drug intermediate ${ }^{17}$. These medicinal properties prompted us to undertake their preparation and evaluate their antimicrobial properties. We now report a convenient, efficient and one-step preparation of some steroidal thiadiazoles 7-9, their characterization and antimicrobial activity, with quantitative yields.

\section{EXPERIMENTAL}

All melting points reported were determined in open capillary tubes and are uncorrected. The IR spectra were recorded on a Perkin Elmer 1600 FTIR spectrometer using Nujol and $\mathrm{KBr}$ pellets. ${ }^{1} \mathrm{H}$ NMR and ${ }^{13} \mathrm{C}$ NMR spectra were recorded in $\mathrm{CDCl}_{3}$ solutions on a Brucker instrument at $300 \mathrm{MHz}$ and $100 \mathrm{MHz}$, respectively, using TMS as an internal standard (chemical shifts in $\delta$, ppm). The mass spectra were run on a Jeol JMS D-300 spectrometer. Elemental analyses were performed on a Heraues CHN Rapid Analyser. Column chromatography purifications were carried out using silica gel (60-120 mesh). Thionyl chloride was freshly distilled.

General procedure for preparation of steroidal thiadiazoles7-9.

Steroidal semicarbazone ${ }^{18} \mathbf{1 - 3}(0.0020 \mathrm{~mol})$ was added portion wise to thionyl chloride ${ }^{19}(6 \mathrm{~mL})$ at ice bath temperature and kept for sometime at room temperature. Then the reaction mixture was stirred at $50^{\circ} \mathrm{C}$ and the reaction progress was monitored by TLC. After completion of the reaction, dichloromethane $(30 \mathrm{~mL})$ was added to the reaction mixture and decomposed with ice cold sodium carbonate solution, till the reaction slowed down. The organic layer was washed with water (4-5 times each with $30 \mathrm{~mL})$ and dried over anhydrous sodium sulphate. The crude product obtained after removal of the solvent was purified by column chromatography over silica gel column. Elution with a mixture of light petroleum and diethyl ether (19:1) provided the respective steroidal thiadiazoles 7-9. Compound 7 was recrystallized from methanol, while compounds $\mathbf{8}$ and $\mathbf{9}$ were found as non-crystallizable semisolids.

Under similar reaction conditions steroidal 6-ketone thiosemicarbazones ${ }^{20}$ 4-6 gave the same products 7-9.

$5 \alpha$-Cholest-6-eno [6, 7-d] thiadiazole (7) was obtained by the procedure described above by stirring the $5 \alpha$-cholestan-6-one semicarbazone 1 with thionyl chloride at $50^{\circ} \mathrm{C}$ for one hour. Yield $72.92 \%$, mp $110-112^{\circ} \mathrm{C}$; IR: 1652 $(\mathrm{C}=\mathrm{C}), 1585(\mathrm{~N}=\mathrm{N}), 1383(\mathrm{C}-\mathrm{N}), 682 \mathrm{~cm}^{-1}(\mathrm{C}-\mathrm{S})$; $\mathrm{H}$ NMR: 0.68 (s, 3H, 18 $\left.\mathrm{CH}_{3}\right), 0.80\left(\mathrm{~d}, \mathrm{~J}=1.28 \mathrm{~Hz}, 3 \mathrm{H}, 26-\mathrm{CH}_{3}\right), 0.87\left(\mathrm{~d}, \mathrm{~J}=1.3 \mathrm{~Hz}, 3 \mathrm{H}, 27-\mathrm{CH}_{3}\right), 0.91(\mathrm{~d}$
$\left.\mathrm{J}=6.3 \mathrm{~Hz}, 3 \mathrm{H}, 21-\mathrm{CH}_{3}\right), 1.10\left(\mathrm{~s}, 3 \mathrm{H}, 19-\mathrm{CH}_{3}\right) ;{ }^{13} \mathrm{C} \mathrm{NMR}\left(\mathrm{CDCl}_{3}\right): \delta 27.2(\mathrm{C}-3)$, 23.1 (C-4), 45.7 (C-5), 155.1 (C-6), 109.5 (C-7), 30.7 (C-8), 48.1 (C-9), 38.5 (C-10), 42.8 (C-13), 56.3 (C-17), 19.8 (C-18), 20.1 (C-19); MS m/z 428 [M+]; Anal. calcd. for $\mathrm{C}_{27} \mathrm{H}_{44} \mathrm{~N}_{2} \mathrm{~S}: \mathrm{C}, 75.64 ; \mathrm{H}, 10.35 ; \mathrm{N}, 6.54$. Found $\mathrm{C}, 75.67 ; \mathrm{H}$, $10.38 ; \mathrm{N}, 6.51 \%$.

On stirring the $5 \alpha$-cholestan-6-one thiosemicarbazone 4 with thionyl chloride at $50{ }^{\circ} \mathrm{C}$ for 3 hours also provided 7 in $65.80 \%$ yield with similar $\mathrm{m}$. p. and spectral data.

3 $\beta$-Acetoxy-5 $\alpha$-cholest-6-eno [6,7-d] thiadiazole (8) was obtained from $3 \beta$-acetoxy- $5 \alpha$-cholestan- 6 -one semicarbazone 2 by stirring with thionyl chloride at $50{ }^{\circ} \mathrm{C}$ for 6 hours as semi-solid. Yield 75.4\%; IR: 1736, 1237 $\left(\mathrm{CH}_{3} \mathrm{COO}\right), 1633(\mathrm{C}=\mathrm{C}), 1540(\mathrm{~N}=\mathrm{N}), 1378(\mathrm{C}-\mathrm{N}), 674 \mathrm{~cm}^{-1}(\mathrm{C}-\mathrm{S}) ;{ }^{1} \mathrm{H}$ NMR: $0.71^{3}\left(\mathrm{~s}, 3 \mathrm{H}, 18-\mathrm{CH}_{3}\right), 0.81\left(\mathrm{~d}, \mathrm{~J}=1.28 \mathrm{~Hz}, 3 \mathrm{H}, 26-\mathrm{CH}_{3}\right), 0.86(\mathrm{~d}, \mathrm{~J}=1.3 \mathrm{~Hz}, 3 \mathrm{H}$, $\left.27-\mathrm{CH}_{3}\right), 0.93\left(\mathrm{~d}, \mathrm{~J}=6.3 \mathrm{~Hz}, 3 \mathrm{H}, 21-\mathrm{CH}_{3}\right), 1.11\left(\mathrm{~s}, 3 \mathrm{H}, 19-\mathrm{CH}_{3}\right), 2.01(\mathrm{~s}, 3 \mathrm{H}$, $\mathrm{CH}_{3} \mathrm{COO}$ ), 4.7 (br m, $1 \mathrm{H}, \mathrm{C} 3 \alpha-\mathrm{H}, \mathrm{W} 1 / 2=16 \mathrm{~Hz}$, axial); ${ }^{13} \mathrm{C}$ NMR : $\delta 71(\mathrm{C}-3)$, 30.1 (C-4), 53.5 (C-5), 155.2 (C-6), 109.5 (C-7), 30.4 (C-8), 48.3 (C-9), 38.2 (C-10), 42.5 (C-13), 56.6 (C-17), 19.3 (C-18), 21.0 (C-19), 170.2 ( $\left.\mathrm{CH}_{3} \mathrm{COO}\right)$, $21.5\left(\mathrm{CH}_{3} \mathrm{COO}\right)$; $\mathrm{MS} m / z 486\left[\mathrm{M}^{+}\right]$; Anal. calcd. for $\mathrm{C}_{29} \mathrm{H}_{46} \mathrm{~N}_{2} \mathrm{O}_{2} \mathrm{~S}$ : C, 71.56 ; $\mathrm{H}, 9.52 ; \mathrm{N}, 5.75$. Found: $\mathrm{C}, 71.61 ; \mathrm{H}, 9.55 ; \mathrm{N}, 5.72 \%$.

Here also the treatment of $3 \beta$-acetoxy- $5 \alpha$-cholestan-6-one thiosemicarbazone 5 with thionyl chloride at $50{ }^{\circ} \mathrm{C}$ for 10 hours provided the same compound $\mathbf{8}$ as semi-solid in $69.3 \%$ yield, with identical spectral and physical data.

3 $\beta$-Chloro-5 $\alpha$-cholest-6-eno $[6,7-d]$ thiadiazole (9) was obtained from $3 \beta$-chloro- $5 \alpha$-cholestan-6-one semicarbazone 3 by stirring with thionyl chloride at $50{ }^{\circ} \mathrm{C}$ for 2 hours as semi-solid. Yield $70.10 \%$; IR: $1628(\mathrm{C}=\mathrm{C})$, $1485(\mathrm{~N}=\mathrm{N}), 1380(\mathrm{C}-\mathrm{N}), 740(\mathrm{C}-\mathrm{Cl}), 645 \mathrm{~cm}^{-1}(\mathrm{C}-\mathrm{S}) ;{ }^{1} \mathrm{H}$ NMR $: \delta 0.65(\mathrm{~s}$, $\left.3 \mathrm{H}, 18-\mathrm{CH}_{3}\right), 0.83\left(\mathrm{~d}, \mathrm{~J}=1.2 \mathrm{~Hz}, 3 \mathrm{H}, 26-\mathrm{CH}_{3}\right), 0.85\left(\mathrm{~d}, \mathrm{~J}=1.27 \mathrm{~Hz}, 3 \mathrm{H}, 27-\mathrm{CH}_{3}\right)$, $0.95\left(\mathrm{~d}, \mathrm{~J}=6.3 \mathrm{~Hz}, 3 \mathrm{H}, 21-\mathrm{CH}_{3}\right), 1.15\left(\mathrm{~s}, 3 \mathrm{H}, 19-\mathrm{CH}_{3}\right), 4.15(\mathrm{br} \mathrm{m}, \mathrm{C} 3 \alpha-\mathrm{H}, \mathrm{W}$ $1 / 2=17 \mathrm{~Hz}$, axial); ${ }^{13} \mathrm{C}$ NMR : $\delta 60.3(\mathrm{C}-3), 38.0(\mathrm{C}-4), 39.8(\mathrm{C}-5), 155.7(\mathrm{C}-$ 6), 109.3 (C-7), 30.3 (C-8), 48.8 (C-9), 39.1 (C-10), 43.0 (C-13), 57.0 (C-17), 19.5 (C-18), 20.5 (C-19); MS m/z 462/464 [M+]; Anal. Calcd for $\mathrm{C}_{27} \mathrm{H}_{43} \mathrm{~N}_{2} \mathrm{SCl}$ : C, 70.01; H, 9.36; N, 6.05. Found: C, 70.05; H, 9.31; N, 6.06\%. Beilstein test positive.

Further stirring 6 with thionyl chloride under similar reaction conditions for 7 hours also provided 9 as semi-solid in $64.0 \%$ yield.

In vitro antibacterial activity

The in vitro antimicrobial activities of corresponding steroidal thiadiazoles 7-9 were

screened for their antibacterial activity against the bacterial cultures of staphylococcus aureus (ATCC29213), Staphylococcus epidermidis (ATCC29887), Escherichia coli (ATCC-8739) and Peseudomanas aeruginosa (ATCC 25619) by disc diffusion method ${ }^{21,22}$. Standard inoculums $\left(1 \times 10^{7}-2\right.$ $\left.\times 10^{7}\right)$ c.f.u. $\mathrm{ml}^{-1}(0.5 \mathrm{McF}$ arland standards $)$ was introduced onto the surface of sterile agar plates and a sterile glass spreader was used for even distribution of the inoculums. $1 \mathrm{mg}$ of every trial compound was dissolved in $100 \mu \mathrm{DMSO}$ to prepare stock solution and from stock solutions diverse concentrations 10 , $20,25,50$, and $100 \mu \mathrm{g} / \mu 1$ of every trial compound were prepared. After that the compounds of diverse concentrations were poured over disk plate onto 
it. The discs measuring $6 \mathrm{~mm}$ in diameter were prepared from Whatman No. 1 filter paper and sterilized by dry heat at $140{ }^{\circ} \mathrm{C}$ for $1 \mathrm{~h}$. The sterile discs previously soaked in a known concentration of the test compounds were placed in nutrient agar medium. Solvent and growth controls were also kept. Gentamicin was used as positive control. While the disc poured in DMSO was used as negative control. The plates were inverted and incubated for $24 \mathrm{~h}$ at $37{ }^{\circ} \mathrm{C}$. The susceptibility was assessed on the basis of diameter of zone of inhibition against different strains of bacteria. Inhibition zones were measured and compared with standard drug. The bacterial zones of inhibition values are given in Table 1.

Table1: Zones of inhibition of compounds 7-9, standard (gentamicin) and negative control (DMSO) with different bacterial strains.

\begin{tabular}{ccccc} 
Compound & \multicolumn{4}{c}{ Zone of inhibition (mm) } \\
& S. aureus & S. epidermidis & E. coli & P.aeruginosa \\
7 & 18 & 25 & 13 & 15 \\
8 & 13 & 18 & 16 & 20 \\
9 & 12 & 16 & 15 & 18 \\
Gentamicin & 20 & 28 & 24 & 22 \\
DMSO & - & - & - & -
\end{tabular}

\section{In vitro antifungal activity}

For assaying antifungal activity, different fungal strains like Claviceps purpurea (MTCC-1479) and Aspergillus niger (MTCC-281) were taken and antifungal activity was done by agar diffusion method ${ }^{23,24}$. Sabourand agar media was prepared by dissolving peptone $(1 \mathrm{~g})$, D-glucose $(4 \mathrm{~g})$ and agar $(2 \mathrm{~g})$ in distilled water $(100 \mathrm{ml})$ and adjusting $\mathrm{pH}$ to 5.7. Normal saline was used to make a suspension of spore of fungal strain for lawning. A loopful of particular fungal strain was transferred to $3 \mathrm{ml}$ saline to get a suspension of corresponding species. $20 \mathrm{ml}$ of agar media was poured into each petri dish. Excess of suspension was decanted and the plates were dried by placing in an incubator at $37^{\circ} \mathrm{C}$ for $1 \mathrm{~h}$. using an agar punch, wells were made and each well was labelled. $1 \mathrm{mg}$ of every trial compound was dissolved in $100 \mu 1$ DMSO to prepare stock solution and from stock solutions diverse concentrations 10, 20, 25,50 , and $100 \mu \mathrm{g} / \mu \mathrm{l}$ of every trial compound were prepared. After that the compounds of diverse concentrations were poured over disk plate onto it. A control was also prepared in triplicate and maintained at $37^{\circ} \mathrm{C}$ for $3-4$ days. The antifungal activity of each compound was compared with Ketoconazole as standard drug. Inhibition zones were measured and compared with the controls. The fungal zones of inhibition values are given in Table 2.

Table 2: Zones of inhibition of compounds 7-9, standard (ketoconazole) and negative control (DMSO) with different fungal strains.

$\begin{array}{lcc}\text { Compound } & \text { Zone of inhibition }(\mathrm{mm}) & \\ & \text { C. purpuria } & \text { A. niger } \\ 7 & 15 & 16 \\ 8 & 15 & 18 \\ 9 & 17 & 18 \\ \text { Ketoconazole } & 24 & 23 \\ \text { DMSO } & - & -\end{array}$

\section{RESULTS AND DISCUSSION}

\section{Chemistry}

We describe in this paper a simple method for the synthesis of steroidal thiadiazoles 7-9 from corresponding steroidal semicarbazones $\mathbf{1 - 3}$ and thiosemicarbazones 4-6 using thionyl chloride. The reaction was carried out by stirring respective semicarbazones and thiosemicarbazones with thionyl chloride at $50{ }^{\circ} \mathrm{C}$ (scheme-1). The products were obtained through treatment with dichloromethane and sodium carbonate solution, then washing with water and removal of the solvent. The crude product obtained was purified by elution with light petroleum-diethyl ether.

The steroidal 6-ketone semicarbazone 1 on reaction with the excess of thionyl chloride gave the corresponding steroidal 1', 2', 3'- thiadiazole 7 in high yield. The IR spectrum $\left(\mathrm{cm}^{-1}\right)$ of the compound 1 displayed primary bands at $3440(\mathrm{NHCO}), 3341\left(\mathrm{CONH}_{2}\right), 1721(\mathrm{C}=\mathrm{O})$ and $1432(\mathrm{C}=\mathrm{N})$. While the IR spectrum $\left(\mathrm{cm}^{-1}\right)$ of the product 7 showed characteristic bands at $1652(\mathrm{C}=\mathrm{C})$, $1585(\mathrm{~N}=\mathrm{N}), 1383(\mathrm{C}-\mathrm{N})$ and $682(\mathrm{C}-\mathrm{S})$. Thus the appearance of bands in the latter and disappearance of bands of $\mathbf{1}$ confirmed the formation of 7 .

In the ${ }^{1} \mathrm{H}$ NMR spectrum of $\mathbf{1}$, a sharp singlet at $\delta 6.5$ integrating for one proton was assigned to $\mathrm{NH}$ proton (exchangeable with deuterium), a broadened singlet appeared at $\delta 5.9$ integrating for two protons was ascribed to $\mathrm{NH}_{2}$ protons and a two-proton doublet for $\mathrm{C} 7-\mathrm{H}_{2}$ was observed at $\delta 3.3$. These peaks were again not found in the ${ }^{1} \mathrm{H}$ NMR spectrum of compound 7 , which further provided the evidence for the formation of $5 \alpha$-cholest-6-eno[6,7-d] thiadiazole 7.

In ${ }^{13} \mathrm{C}$ NMR of 1 a characteristic peak at around $\delta 33.0$ was observed for C-7, a peak at $\delta 160.4$ was assigned to carbonyl carbon $\left(\mathrm{CONH}_{2}\right)$ of semicarbazone moiety and another peak at $\delta 158.6$ was given for C-6. Especially the ${ }^{13} \mathrm{C}$ NMR spectrum of 7 strongly supported its formation. In the ${ }^{13} \mathrm{C}$ NMR of 7 , a well marked characteristic peak appeared at $\delta 109.5$, which was assigned to C-7 and the reason for this peak may be the change in the hybridization (from $\mathrm{sp}^{3}$ to $\mathrm{sp}^{2}$ ) of $\mathrm{C}-7$ due to formation of double bond between $\mathrm{C} 6-\mathrm{C} 7$. There was a peak at $\delta 155.1$ also which was assigned to C-6. The peaks at $\delta 27.2$ and $\delta 45.7$ were assigned to $\mathrm{C}-3$ and $\mathrm{C}-5$ respectively. These spectral values provided strong evidence of the formation of $5 \alpha$-cholest-6-eno[6,7-d] thiadiazole 7.

In the same way the formation of $\mathbf{8}$ and $\mathbf{9}$ from corresponding steroidal semicarbazone $\mathbf{2}$ and $\mathbf{3}$ was also confirmed by their spectral studies (data given in Table 3 and experimental section).

It was found that steroidal 6-ketone thiosemicarbazones 4-6 (Table 3) under similar reaction conditions on treatment with excess of thionyl chloride provided the products which were found to contain the same spectral data as 7-9 (identical m.p., mixed m.p., TLC).

Thus the study of physical , analytical and spectral data (mixed m.p., IR, ${ }^{1} \mathrm{H}$ NMR, ${ }^{13} \mathrm{C}$ NMR, mass spectrometry and elemental analysis) revealed the formation of same products 7-9 from compounds 1-3 as well as from compounds 4-6.

\section{Antibacterial activity}

The in vitro antimicrobial activities of steroidal thiadiazoles 7-9 were screened for their antibacterial activity against the bacterial cultures of staphylococcus aureus (ATCC29213), Staphylococcus epidermidis (ATCC29887), Escherichia coli (ATCC-8739) and Peseudomonas aeruginosa (ATCC 25619) by disc diffusion method. Standard inoculums $\left(1 \times 10^{7}-2 \times\right.$ $10^{7}$ c.f.u ml $\mathrm{l}^{-1}, 0.5 \mathrm{McFarland}$ standards) were introduced onto the surface of sterile agar plates and a sterile glass spreader was used for even distribution of the inoculums. The susceptibility was assessed on the basis of diameter of zone of inhibition against different strains of bacteria. Inhibition zones were measured and compared with standard drug, Gentamicin. The bacterial zones of inhibition values are given in Table 1. The results indicated that the compound 7 has shown the significant activity against $S$. aureus and $S$. epidermidis while compound $\mathbf{8}$ showed marked activity against $P$. aeruginosa. Other compounds showed moderate to good antibacterial activity.

\section{Antifungal activity}

For assaying antifungal activity, different fungal strains like $C$. purpurea and $A$. niger were taken and antifungal activity was done by agar diffusion method. The antifungal activity of each compound was compared with Ketoconazole as standard drug. Inhibition zones were measured and compared with the controls. The fungal zones of inhibition values are given in Table 2. The antifungal screening data also showed moderate to good fungal inhibition. Among the screened compounds, the compound 9 showed good zones of inhibition against both the strains in comparision with the reference drug ketoconazole.

\section{CONCLUSION}

The present procedure of oxidative cyclization of steroidal semicarbazones and thiosemicarbazones to steroidal thiadiazoles by thionyl chloride is a simple, straight forward and can be easily scaled up. Besides this the reagent is cheap and easily available. Thus by this method we can synthesize steroidal thiadiazoles 7-9 in quantitative yields. The antimicrobial activities including antibacterial and antifungal properties of the synthesized compounds 7-9 showed a significant activity as compared with standard drugs.

\section{ACKNOWLEDGEMENTS}

Authors thank the Chairman, Department of Chemistry, A.M.U., Aligarh and Chairman, Department of Illmul Advia, Ajmal Khan Tibbiya College , AMU, Aligarh for providing necessary research facilities. 
Table 3: Characterization data of compounds 1-6.

\begin{tabular}{|c|c|c|c|c|}
\hline Compound & Mol. Formula & $\mathrm{I} \mathrm{R}\left(\mathrm{cm}^{-1}\right)$ & $\begin{array}{l}{ }^{1} \mathrm{H} \text { NMR } \\
(\delta, \mathrm{ppm})\end{array}$ & $\begin{array}{c}{ }^{13} \mathrm{C} \mathrm{NMR} \\
(\quad \delta, \mathrm{ppm})\end{array}$ \\
\hline 1 & $\mathrm{C}_{28} \mathrm{H}_{49} \mathrm{~N}_{3} \mathrm{O}$ & $\begin{array}{c}3440(\mathrm{NHCO}), \\
3341\left(\mathrm{CONH}_{2}\right), 1721(\mathrm{C}=\mathrm{O}), 1432(\mathrm{C}=\mathrm{N})\end{array}$ & $\begin{array}{c}\text { 6.5(s,1H,NH }), \\
5.9\left(\mathrm{~s}, 2 \mathrm{H}, \mathrm{NH}_{2}\right), \\
3.3\left(\mathrm{~d}, 2 \mathrm{H}, \mathrm{C} 7-\mathrm{H}_{2}\right)\end{array}$ & $\begin{array}{c}\mathrm{C} 6=158.6, \\
\mathrm{C} 7=33.0, \\
\mathrm{CONH}_{2}=160.4\end{array}$ \\
\hline 2 & $\mathrm{C}_{30} \mathrm{H}_{51} \mathrm{~N}_{3} \mathrm{O}_{3}$ & $\begin{array}{c}3435(\mathrm{NHCO}), 3343 \\
\left(\mathrm{CONH}_{2}\right), 1714(\mathrm{C}=\mathrm{O}), \\
1412(\mathrm{C}=\mathrm{N})\end{array}$ & $\begin{array}{c}6.3(\mathrm{~s}, 1 \mathrm{H}, \mathrm{NH}), \\
5.8\left(\mathrm{~s}, 2 \mathrm{H}, \mathrm{NH}_{2}\right), \\
2.9\left(\mathrm{~d}, 2 \mathrm{H}, \mathrm{C} 7-\mathrm{H}_{2}\right)\end{array}$ & $\begin{array}{c}\mathrm{C} 6=158.8, \\
\mathrm{C} 7=33.5, \\
\mathrm{CONH}_{2}=160.0\end{array}$ \\
\hline 3 & $\mathrm{C}_{28} \mathrm{H}_{48} \mathrm{~N}_{3} \mathrm{OCl}$ & $\begin{array}{c}3420(\mathrm{NHCO}), 3246 \\
\left(\mathrm{CONH}_{2}\right), 1705(\mathrm{C}=\mathrm{O}), \\
1395(\mathrm{C}=\mathrm{N}), 770(\mathrm{C}-\mathrm{Cl})\end{array}$ & $\begin{array}{c}6.1(\mathrm{~s}, 1 \mathrm{H}, \mathrm{NH}), \\
5.5\left(\mathrm{~s}, 2 \mathrm{H}, \mathrm{NH}_{2}\right), \\
2.5\left(\mathrm{~d}, 2 \mathrm{H}, \mathrm{C} 7-\mathrm{H}_{2}\right)\end{array}$ & $\begin{array}{c}\mathrm{C} 6=158.4, \\
\mathrm{C} 7=33.1, \\
\mathrm{CONH}_{2}=160.2\end{array}$ \\
\hline 4 & $\mathrm{C}_{28} \mathrm{H}_{49} \mathrm{~N}_{3} \mathrm{~S}$ & $\begin{array}{c}3510(\mathrm{NHCS}), 3370 \\
\left(\mathrm{CSNH}_{2}\right), 1590(\mathrm{C}=\mathrm{N}) \\
1180(\mathrm{C}=\mathrm{S})\end{array}$ & $\begin{array}{c}8.8(\mathrm{~s}, 1 \mathrm{H}, \mathrm{NH}), \\
6.3\left(\mathrm{~s}, 2 \mathrm{H}, \mathrm{NH}_{2}\right), \\
2.5(\mathrm{~d}, 2 \mathrm{H}, \mathrm{C} 7- \\
\left.\mathrm{H}_{2}\right)\end{array}$ & $\begin{array}{c}\mathrm{C} 6=158.2, \\
\mathrm{C} 7=35.3, \\
\mathrm{CSNH}_{2}=183.0\end{array}$ \\
\hline 5 & $\mathrm{C}_{30} \mathrm{H}_{51} \mathrm{~N}_{3} \mathrm{O}_{2} \mathrm{~S}$ & $\begin{array}{c}3500(\mathrm{NHCS}), 3355 \\
\left(\mathrm{CSNH}_{2}\right), 1735(\mathrm{OCO} \\
\left.\mathrm{CH}_{3}\right), 1590(\mathrm{C}=\mathrm{N}), \\
1175(\mathrm{C}=\mathrm{S}), 1040 \\
(\mathrm{C}-\mathrm{O})\end{array}$ & $\begin{array}{c}9.2(\mathrm{~s}, 1 \mathrm{H}, \mathrm{NH}), \\
6.5\left(\mathrm{~s}, 2 \mathrm{H}, \mathrm{NH}_{2}\right), \\
3.0(\mathrm{~d}, 2 \mathrm{H}, \mathrm{C} 7- \\
\left.\mathrm{H}_{2}\right)\end{array}$ & $\begin{array}{c}\mathrm{C} 6=158.6, \\
\mathrm{C} 7=35.0 \\
\mathrm{CSNH}_{2}=183.2\end{array}$ \\
\hline 6 & $\mathrm{C}_{28} \mathrm{H}_{48} \mathrm{~N}_{3} \mathrm{SCl}$ & $\begin{array}{c}3515(\mathrm{NHCS}), 3350 \\
\left(\mathrm{CSNH}_{2}\right), 1580(\mathrm{C}=\mathrm{N}), \\
1170(\mathrm{C}=\mathrm{S}), 750(\mathrm{C}-\mathrm{Cl})\end{array}$ & $\begin{array}{c}9.2(\mathrm{~s}, 1 \mathrm{H}, \mathrm{NH}), \\
6.4\left(\mathrm{~s}, 2 \mathrm{H}, \mathrm{NH}_{2}\right), \\
3.5(\mathrm{~d}, 2 \mathrm{H}, \mathrm{C} 7- \\
\left.\mathrm{H}_{2}\right)\end{array}$ & $\begin{array}{c}\mathrm{C} 6=158.2, \\
\mathrm{C} 7=35.7 \\
\mathrm{CSNH}_{2}=183.6\end{array}$ \\
\hline
\end{tabular}

\section{REFERENCES}

1. A. H. Mandour, T. H. El-Shihi, A. A. Nehad, Z. E. El-Bazza, Phosphorus, Sulfur, Silicon Rela. Elem. 113, 155 (1996).

2. A. A. Aly, R. El-Sayed, Chem. Pap. 60, 56 (2006).

3. B. E. Bayoumy, M. A. Abd-Alla, A. N. Ahmed, Bull Pharm. Sci. 9(2), 66 (1986).

4. M. J. Pawar, A. B. Burungale, B. K. Karale, ARKIVOC, xiii, 97 (2009).

5. S. A. Mayekar, V. V. Mulmad, Indian J Chem. (B), 47, 1438, 2008.

6. C. S. Reddy, D. C. Rao, V. Yakub, A. Nagaraj, Indian J chem.(B), 50, 253, 2011.

7. V. Athanasia, T. K. Anna, S. P. Theodora, T. Ekaterim, Arzaeim Forsch 50(1), 48 (2000).

8. Z. Ziyi, H. Yang, Youji Huaxue 8(2), 153 (1988).

9. M. Santus, Acta. Pol. Pharm. 45(3), 219 (1988).

10. N. Siddiqui, Himalayan Chem. Pharm. Bull. 17, 16 (2000).

11. B. E. Bayoumy, A. Deeb, M. El-Mobayed, M. A. Abd-Alla, Egypt. J. Chem. 30(1), 53 (1987).

12. S. Andotracharanjit, S. Sharma, Proc. Acad. Sci. India 58(2), 215 (1988).

13. Z. Zhang, K. Yang, F. Zeng, Gaodeng Yuexiao Huaxue Yuebao 9(3), 239 (1988).

14. X. Qian, R. Zhang, G. Song, H. Yu, Chem. Abstr. 134, 4937u (2001).

15. S. Rollas, Eczacilik Fak. Mecm. 18, 3 (1982).

16. A. A. El-Emam, M. A. Moustafa, M. A. El-Kerdawy, J. Mansoura Pharm. Sci. 3, 89 (1988).

17. D. Lehmann, R. Eckardt, G. Faust, W. Fiedler, W. Poepel ,H. J. Jaensch, H. J. Heidrich, D. Lohmann, Chem. Abstr. 111, 134167d (1989).

18. Shafiullah, A. A. Shahid, J. Indian Chem. Soc. 67, 431 (1990).

19. C. D. Hurd, R. I. Mori, J Am. Chem. Soc.77, 5359 (1995).

20. Shamsuzzaman, A. Salim, M. Aslam, F. Naqvi, Synth. Commun. 27, 2171 (1997).

21. R. Cruickshank, J. P. Duguid,B. P. Marmion R.H.A. Swain, 1975, Medical Microbiology, 12th ed., vol. II, Churchill Livingstone,London, pp 196-202.

22. A. H. Collins, 1975. Microbiological methods, fourth ed. Butterworth, London.

23. Z. K. Khan, Proc. Int. workshop UNIDO-CDRI, 210-211, 1997.
24. R. S. Verma, I. K. Khan, A. P. Singh. Antifungal agents: Past, Present, Future prospects. National Academy of chemistry and biology, Lucknow, India 1998. 